\title{
Good Dances Make Good Guests: Dance, Animation and Sovereign Assertion in 'Amis Country, Taiwan
}

\author{
DJ W. Hatfield Berklee College of Music
}

acteurs, supports et interprétations, souvent d'une manière qui fait obstacle à l'interprétation. Ainsi, l'attention portée à la malikoda met en évidence la façon dont les peuples autochtones investissent l'autochtonie comme ressource culturelle dans le cadre du multiculturalisme, et soulève des questions plus larges sur le rôle de l'animation dans l'affirmation de la souveraineté.

Mots clés : animation, autochtonie, multiculturalisme, souveraineté, danse, Taiwan

\section{"Is It OK to Penetrate the Dancers?" - Managing Guests}

In the wee hours of the morning on 16 July 2014, the Lakancin age set of the 'Atolan 'Amis Community relaxed after a long day of managing 'Atolan's annual festival (kiloma'an). ${ }^{1}$ Named for NASA astronaut and the first ethnic Chinese person to go into space, Taylor Gun-jin Wang (Wang Gan-jun), Lakancin came of age in 1985 around the time of Wang's voyage on the space shuttle Challenger. Serving as the mikomoday age grade responsible for administering the community, Lakancin had one more year before they handed down their responsibility to the age set just "downstream" of them. ${ }^{2}$ Tonight, the men were taking a breath before another day's work.

"Kakaaw! Icowa ko lalan?" - Elder brothers! Where is the path? - came the shout from outside the patio wall. Representatives from Lakayakay, the downstairs age set named for the 1990 construction of the Chunghua Bridge, had come to ask their upstairs age set a few questions. Straightening up their regalia and moving guests outside of their circle, Lakancin invited their younger brothers to enter. One of the representatives from Lakayakay asked the following question about malikoda, a ritual dance nearly synonymous with kiloma'an: "During the annual festival (dance) [likoda], is it okay for tourists to penetrate [mipacok] the dancers?"

Lakancin laughed. Chiding the younger brothers for using such a suggestive verb, Lakancin's leader 
said that although they wished to restrict the entrance of visitors to the end of the dance spiral, a few of the senior age sets were perhaps a bit too accommodating. "We might not like how our upstream age sets let so many tourists into the dance," said the leader, "but our older brothers have a point: The dance is our prayer and should be orderly and beautiful; but when guests come to see us, it is our honour to include them. With the guests in the right place the likoda will be even more beautiful."

A guarded answer. Upstream of Lakancin, senior men claimed the visitors to kiloma'an as a source of pride. The newer shoots of the age set system, however, pushed against Lakayakay, with demands that tourists be kept out as they have been in several other 'Amis/ Pangcah communities. I doubted that those young people would accept such a response. As they prepared to administer the community in 2015, Lakayakay had to form a policy that both accommodating seniors and strident youth could embrace.

Once Lakancin had swept up, I visited Lakayakay. Talking about the question and laughing about its wording, Lakayakay's women concurred that they would never let Paylang, members of Taiwan's majority ethnic Chinese settler colonial population, pacok them.

"Of course," retorted one of the men, "You are all Paylang women who married 'Amis!"

I laughed. His remark set me off balance, however. Those most strident about tourists at kiloma'an often resided in urban centres on the west coast, visiting only on holidays. Or they, like the married women or a number of new residents in the village, were adopted into the community. Most of us considered malikoda in terms of ritual or heritage but (ironically, given our own inclusion in the dance) less often as an act of hospitality.

Disputes concerning malikoda concerned the ethics of hospitality, as well as problems of heritage. The ritual of holding hands to dance generated contrasting positions on these issues because the dance mediates categories of age and gender within the community and engages with external powers, often incorporating them. In regard to tourists entering the dance, the general mood was ambivalence and not rejection. Most in the 'Atolan 'Amis community recognise that at least part of the day's dance should include some non-'Amis guests. And so, the community had to establish a protocol for taking the visitors in hand and pulling them into the malikoda's weave. Only then would the dance be complete. But how to align all of the different agents - ancestors, community members, Indigenous and settler guests, photography enthusiasts, government officials, tourists - in the right way?

\section{If Good Fences Make Good Neighbours, Do Good Dances Make Good Guests?}

Although a current of thinking about musical participation (Keil 1987; Turino 2008) celebrates the power of musical practices to generate communitas where once there was division, musical participation tends to uphold social boundaries even as it mediates them. Participatory musical practices have an ironic relationship to enrolment and closure, affording less an experience of undifferentiated humanity than commentary on what it might mean to belong to a particular social group, to be an insider, an outsider or a guest. Like fences in Robert Frost's poem "Mending Wall" (1914), closure in musical practices is a kind of affordance that might make good guests (as well as good neighbours). As participatory musical practices often feature in protest and acts of sovereign assertion among Indigenous people in Taiwan and elsewhere (Martineau 2015), attending to these participatory musical practices reveals how sovereignty is often a figure animated at the boundaries of settler and Indigenous communities. Good dances make good guests.

In their concern with who could dance, Lakancin and Lakayakay engaged in acts to maintain their control over how their community interacts with outsiders, ensures its future and appears in cultural circulation. I call these acts sovereign assertion. By talking about sovereign assertion, I wish to call attention to a variety of communicative acts in which enduring responsibilities and relations are enacted, rather than focusing upon a reified notion of sovereignty as a substance possessed by corporate persons in varying quantity.

I define sovereign assertion as a set of means through which Indigenous people assert their continued existence as polities: organised groups with their own principles, practices and structures through which they govern themselves as custodians of the lands and ocean that sustain them. Malikoda, a genre of dances performed holding hands while singing and moving in a spiral pattern, figures as a form of sovereign assertion because of its associations with community ritual and boundaries, as well as its broad circulation as a symbolic token of indigeneity. Pangcah scholar Panay Mulu (2008, 2010) describes the dance as both a "weave" of bodies, land and ancestors and a lalan (way/path) to communicate with ancestors. 'Amis and other Taiwanese Indigenous people malikoda when engaged in celebration or political protest, in a variety of inter-ethnic, intercommunal, community and family contexts. Through these circulations, the gesture of holding hands to dance has become a kinesthetic symbol of Indigenous Taiwan in general, as well as a "root metaphor" that Taiwanese Indigenous people employ in 
relationships with the settler colonial population (Chao 2009; Wang Ying-fen 2008). It is a source of pleasure and also anxiety - for 'Amis people, who find themselves both welcoming and worried when they take non-Amis guests by the hand and into the spiral.

Anxiety surrounding malikoda surfaces in arguments concerning who may dance and for what purposes: Is the dance intangible heritage, a means of ancestor worship, a military review or a ritual of hospitality? These arguments all refuse some settler participation or knowledge of malikoda while articulating, or becoming complicit with, other settler discourses or bids to participate. They are attempts to negotiate a framework in which the dance can be effective across social contexts. Moreover, this negotiation, as in the case I describe above, centres on how to align the commitments and stances of disparate participants into a single figure. Looking at arguments about how good dances might make good guests could tell us a great deal about how sovereignty comes to be animated and embodied in musical and other cultural practices.

To make this argument, I first provide background on 'Amis history. After a discussion of how this ethnographic case connects to anthropological conversations about sovereignty, I contrast two ways that 'Amis people have engaged in negotiation about, and through, dance. The first of these, heritage, seeks to employ legal regimes to assert control over dance as a cultural property. We saw the second, hospitality, when Lakancin's leader said that incorporating guests would make the dance even more beautiful. Rather than claiming rights to heritage circulating in a multicultural public sphere, hospitality configures dance as a means to extend relationships and to assert the community's role as a host to whom guests must defer. Although heritage regimes tend to rely on the state as an arbiter, 'Amis notions of hospitality may contribute to how we imagine non-statecentric forms of political community.

\section{The Niyaro' and the State}

'Amis/Pangcah encountered colonial powers as part of the global expansion of capitalism in the 1600s. Emblematic of that expansion, the name of a mountain just north of the Siuguluan River in the Makota'ay Pangcah community, Kakowangan, commemorates a Dutch fortification and Pangcah attempts to use a cannon (kakowang) to repulse Qing imperial soldiers in 1877. Like other Taiwanese Indigenous Peoples, 'Amis descend from Austronesian peoples who inhabited the island several millennia prior to the ethnic Chinese settler colonial presence on Taiwan. The Dutch, who brought the cannon to Kakowangan, also imported ethnic Chinese labour, the ancestors of Taiwan's majority settler population. Although the Beijing-based Qing empire annexed Taiwan in 1683, intensifying the process of settler colonialism on Taiwan's west coast, the Pacific coast was not brought under control of the Qing state until the $1880 \mathrm{~s}$, just before the Japanese colonial period began in 1895 . Today, 'Amis live in urban centres on the west coast, as well as in their traditional country along the Pacific coast and East Rift Valley. Included under civil administration under the Japanese, they now live amid large settler populations even in their own communities and, unlike upland Indigenous groups, have no reservation land. Their current population of 203,000 makes this group the largest of Taiwan's Indigenous groups (CIP 2018).

'Amis maintain a sense of their endurance in spite of administrative invisibility. Unlike most Indigenous nations in North America, 'Amis and other Taiwanese Indigenous Peoples have never had treaty relationships with successive colonial governments. Today, under the Republic of China (ROC) government that has ruled Taiwan since 1945, Taiwan's Indigenous communities lack administrative reality. Currently, no equivalent exists to reservation, tribal or band governments in Taiwan. Indigeneity is rather a category of individual (ethnic) identification certified by the settler government. Nonetheless, 'Amis maintain a sense of their communities as distinct polities. Niyaro', an 'Amis term derived from a term for the bamboo enclosures that often protected their communities, continue to be organised through age set organisations (kapot, slal). This system provided for labour mobilisation, defence and mediation with other polities, including colonial states - as it still does today.

From 1994 onward, Taiwanese Indigenous groups have achieved constitutional recognition as Indigenous Peoples whose affairs are administered partially through an Indigenous staffed Council for Indigenous Peoples (CIP). The current constitution guarantees representation to Taiwanese Indigenous Peoples, with 6 legislative seats out of the total 113 reserved for Indigenous representatives. Many political developments emerging since the late 1990s and early 2000 s have explicitly borrowed terms like New Relationship of Partnership and Mutual Respect from the Canadian Royal Commission on Aboriginal Peoples (RCAP) model. Announcements of the "New Relationship" by the Presidential Office in 2000 referred explicitly to the "natural sovereignty" (ziran zhuquan; might also gloss inherent sovereignty) of Indigenous Peoples, usage that by 2002 was, according to legal scholar Shih Cheng-fong (2012, 38), "uncontroversial." Nevertheless, the Indigenous Basic Law (yuanzhuminzu jibenfa; IBL) employs the term rights to autonomy (zizhiquan) rather than sovereignty. 

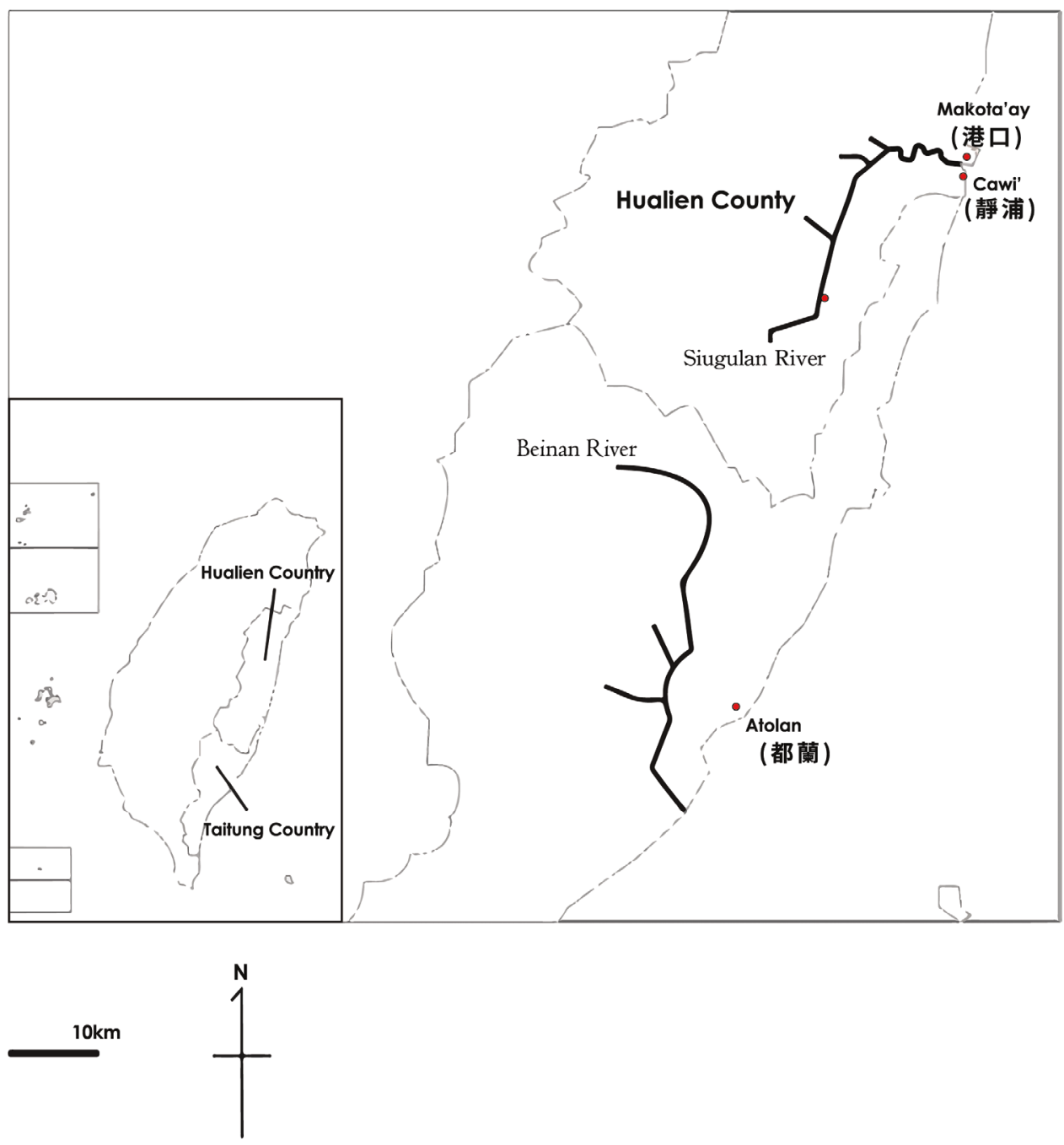

Figure 1: Map of Taiwan showing locations of 'Atolan, Cawi' and Makota'ay.

Source: Map by Cheng Chih-ying.

With ongoing changes in the Taiwan (ROC) government's relationship with Indigenous communities, revisions to the IBL in 2015 called for the creation of Indigenous public corporations (buluo gongfaren). In her historic 2016 apology to Taiwanese Indigenous Peoples, President Tsai Ying-wen reiterated the government's resolve to establish these corporations as a means to achieving Indigenous autonomy (Tsai 2016). Public corporations of Taiwan are legal persons with some coercive power. They include the national government as well as local governments and the irrigation authority. In Atolan, problems of jurisdiction led to the failure to incorporate as a public corporation; the niyaro' currently has the status of social corporation, something like an NGO. The process of establishing Indigenous corporations prompted many arguments within Indigenous communities concerning who should belong to such corporations, their administrative structure and the scale at which they should operate (Kao Te-yi 2016; Semaylay 2017). Because the settler state maintains its right to establish procedures to certify and administer the corporations, they may act to reduce Indigenous polities to the status of municipalities; the processes for certification also constrain the form of political community to those legible to, and in compliance with, the settler state. In this regard, the process for incorporation resembles the operation of recognition in other settler colonial states (Coulthard 2014; Nadasdy 2017; Povinelli 2002).

\section{Sovereign Assertion as Animation}

Sovereignty has emerged over the past several years as a key word in the discipline of anthropology. ${ }^{3}$ This body of work has added to anthropological understandings of the state, yet it usually fails to approach what most 
Taiwanese Indigenous people mean by sovereignty as a value of Indigenous political movements, not to mention in the lives of working class 'Amis people with whom I work in the niyaro'. In thinking about dance and sovereign assertion, we must ask whether it is possible to move beyond state-centric definitions of the term.

Continuing my ethnographic example, people in the niyaro' rarely employ the translation of sovereignty into Mandarin, zhuquan; however, many 'Amis people do stress that their ancestors' footsteps are part of the land. They also stress that Indigenous people are Taiwan's "true masters" (zhenzheng de zhuren), employing a term for host, master or owner (zhuren) that employs the first character in the Mandarin translation of sovereignty, $z h u$. To demonstrate their status as zhu, 'Amis people point out that the age set system, with its graded set of responsibilities to the niyaro', still configures life in 'Amis communities. Maintenance of the age set system asserts that the community remains self-organised and responsible to its land and ancestors.

Sovereign assertion takes many forms but generally makes claims for modes of autonomy in contexts marked by colonial dependence. In response to depictions of Indigenous people as ethnic minorities contained within the multicultural polities and welfare regimes of settler colonial states, sovereignty remains a "strategy of ... reasserting a politically empowered self-identity" (Barker 2005, 20; see also Turner 2006).

Although there is no single definition for sovereignty as it has come to be employed in diverse Indigenous contexts, the term usually refers to notions of self-organisation and independence. A recent account of sovereignty discourse in Indigenous North America, for example, provides a list of possible definitions, including authority to decide the form and limits of governmental structures and their relationships to other such structures, the right to have autonomous control over a territory, and a "shorthand for the right to self-determination and the correlated ability to independently make key decisions concerning land, livelihood, and the opportunities available to future generations" (Willow 2013, 872-873). Aware that these notions of sovereignty are often entangled with settler institutions (Cattelino 2008), multilayered (Biolsi 2006; Blackburn 2009; Hodgson 2002) and at odds with conventional definitions of sovereignty in the discipline of anthropology, recent anthropological scholarship on sovereignty in Indigenous settings (Cattelino 2010; Rifkin 2017; Simpson 2014; Sturm 2017) has endeavoured to expand discussion beyond considerations of domination or constitutive violence, particularly as sovereignty has offered a new language for Indigenous people to press claims against settler colonial states.
Another body of critical scholarship (Alfred [1999] 2009, 2005; Barker 2005; Corntassel 2012a; Coulthard 2010, 2014; Nadasdy 2012, 2017; Steinman 2016) cautions that the notion of sovereignty might distort Indigenous political philosophies and political organisation on the ground. In his work on resurgence, Jeff Corntassel (2012a) argues that discourses of rights and sovereignty distract from Indigenous movements aimed at resurgence and responsibility to land. Although seeing the pragmatic value of sovereignty discourse among Indigenous people in North America, Taiaiake Alfred ([1999] $2009,80-81$ ) points out that sovereignty is incompatible with Indigenous movements for resurgence because it depends upon a model of "coercive force, control of territory, population numbers, and international recognition." Resonating with Alfred's critique of sovereignty, Nadasdy (2017) demonstrates that use of the term requires people to reorganise their relationships according to a number of "cultural entailments" - assumptions about governance and community that are often at odds with local social organisation. In this context, "empowerment" is thus also a "form of subjection" in which Indigenous people have been compelled to "alter their personhood and society" (Nadasdy 2012, 500). Aware of this effect, Nadasdy (2017, 9) worries that the assumptions that we adopt when we employ concepts associated with sovereignty "enable some sorts of politics and foreclose others."

This sense that the dominance of state-centric notions of political community forecloses political possibilities informs scholars critical of the anthropological turn to sovereignty. In his trenchant critique of the sovereignty literature, for example, Ronald Jennings (2011) describes fascination with sovereignty as a politically disabling distraction. He suggests that anthropologists begin to develop a "positive framework for political thought" (52), allowing us to imagine possibilities beyond sovereignty. Such a project has already been advanced by Native Studies scholars. As early as 1999, Alfred ([1999] 2009,78 ) challenged his readers to "create a meaning for sovereignty that respects the understanding of power in Indigenous cultures." In her discussion of resurgence, Leanne Betasamosake Simpson (2013) describes a radiating set of relationships in which a political community is "not based on enclosures defended with violence." Arguing that scholars have often missed decolonising strategies that neither engage in struggles over formal sovereignty nor push for multicultural inclusion, Erich Steinman $(2016,220)$ suggests that scholarship be more attentive to "distinctive decolonizing actions" in relationship to specific dimensions of settler colonialism. ${ }^{4}$

Ambivalence surrounding sovereignty suggests that we might adopt an approach in which we view the concept 
as more than just a singular object but a constellation of related possibilities. Aware that movements for resurgence may remediate some of sovereignty's cultural entailments while remaining anti-statist (if not anti-sovereign; Nadasdy 2017), we might also focus on sovereign assertion as animated through communicative acts rather than on sovereignty as a quality whose gain and loss is always zero-sum. Asch, Borrows and Tully $(2018,9)$ provide a sense of what such an approach might look like in a recent work in which they stress ongoing, often contentious engagement that never assumes (or expects) that communication will end with a "fusion of horizons."

Returning to my ethnographic example, as "Amis people engage with the settler community through malikoda, they are aware that interpretations of the dance may not achieve unanimity but will shift across communities, media and different levels of scale. In this regard, malikoda establishes what Sherry Pictou (2015) calls, following the work of James Tully, "small ' $t$ ' treaty relations." Like the activism of M'ikmaq clam harvesters Pictou (2015, 465) describes, malikoda operates within "multi-sited and multi-scalar contexts" and creates a "'weaving' of new relations that could only develop outside a political/knowledge economy in which formal treaty negotiations are embedded."

As members of Lakancin and Lakayakay argued about tourists and aesthetic qualities of the dance, they had to rely upon resources inside and outside their conversation, including images of the dance circulating in Taiwanese popular culture and CIP-certified images of 'Amis heritage. They also had to shift among canonical meanings of the dance within their community and interpretations given the dance by settler visitors, attempting to find some alignment among them that would bring the community's assertion into relief. Lakancin was caught up with a dilemma: if too many visitors danced, the malikoda would become chaotic and the ritual would fail; but were no visitors to dance, it would be impossible to align the visitors with a realisation of the niyaro' as a powerful host.

This problem of alignment suggests how sovereign assertion might be considered an example of animation. In her work on sovereignty movements in West Papua, Danilyn Rutherford $(2012,2)$ argues that the "pursuit of sovereignty inevitably entails an encounter with spectators: audiences in all their myriad forms." In pointing out the role of the audience, Rutherford demonstrates one of sovereignty's contradictions: it promises a "dream of overcoming one's dependence on others" (21) but requires alignment among disparate media and the enrolment of persons from spatiotemporally and culturally distinct frames of reference (see also Cocks 2014).
Yet, more than audience infects sovereign assertion. As noted by Michael Asch (2014), sovereignty as developed in western political philosophy derived from a fear that lacking a single, dominating figure (the sovereign), there would be no way to enforce contracts. Seen in this light, sovereignty is not performative, as argued by Rutherford (2012); rather, it responds to doubts concerning the possibility of performatives to remain felicitous. Thus, in his work, Asch (2014, 116-133) attends to gestures and material cultures of treaties, arguing that treaties extend a "linking principle" in which distinct groups maintain their distinctness but also recognise their mutuality. While I recognise in malikoda a similar linking principle, my focus in this article is on animation: in other words, I examine how through their attempts to enrol visitors as co-animators and align the dance across different media, 'Amis people brought the figure of the niyaro' into resolution. Sometimes this figure appears state-like or entangled with the state; however, malikoda also animates a possibility for relatedness beyond the state.

Aware that animation might be an unfamiliar concept to some readers, I give a brief definition below.

First, animation is a type of collective work that projects life, agency or will into characterological figures (Manning and Gershon 2013; Silvio 2010, 2019). These figures may include conventional animated characters, but animation may also project agency onto symbolic figures, abstractions and material objects (Manning 2010; Nozawa 2013). Often, the effect of animation is the result of alignment across disparate media (Silvio 2010). This work of many people producing a character with human attributes, such as voice, is a signal feature of animation as opposed to performance.

Second, animation has to do with a decomposition of the speaking subject into many possible "production formats" (Goffman 1974). Animators voice (or realise) communicative acts or gestures (Goffman 1974; see also Kockelman 2004). Often, these communicative gestures are authored (or composed) by some other persons, the authors. Moreover, the persons responsible for or committed to the communicative act (the principals) may differ from both authors and animators. Because these roles are stances (as well as actions) adopted in relationship to a communicative act, they often shift during communicative events. In this second sense, animation suggests types of spatiotemporal distance between those who compose or maintain commitment to a communicative act and those who give it voice (Kockelman 2004).

Animation thus suggests potential differences of interpretation and commitment among principals, authors and animators - who are all, however, engaged in the 
communicative act. Unlike performatives, whose basic felicity conditions (Austin 1962) include both a warrant to perform and commitment to the performative act (sincerity), felicity conditions for animation stress aesthetic fidelity. Animators need only produce the communicative act as authored; their commitment to the communicative act's truth or outcomes remains inessential. To return to our example, guests pulled into the malikoda's spiral animate the dance when they realise it beautifully; whether the dance succeeds as an assertion depends on how principals of the event have aligned it across the interpretive frameworks that it needs to travel. The principals may choose to align it across several frameworks or to maintain only the most local framework of the dance. This question of alignment has bearing upon sovereign assertion, as we will see below.

Animation places problems of stance, scale and closure in greater relief. The strength and weakness of malikoda is that it relies on a set of embodied dispositions that, while effective in securing assent to local political categories during the ritual, may not be intelligible to guests once the dancing has ended. Do good dances make good guests? This may depend on how closure is maintained and understood beyond the performance.

\section{Dance and Mediating Difference}

Although malikoda tunes and gestures are peculiar to each niyaro', all likoda follow a general pattern. First, they are participatory dance songs sung, with no instrumental accompaniment, nearly entirely in the vocables ho hay yan, and nalowan. Dancers perform the dance holding hands in a spiral, which may move in either a clockwise or counter-clockwise direction. Musically, the dance repeats a four-to-eight bar structure. The response may repeat the call, form a refrain or overlap with it; however, the response tends to be relatively fixed and the call relatively elaborated, with the possibility of improvised phrases and lyrics that describe the situation of the dance. The repetitive phrases, continuous pulse, full-volume singing and dense timbre produced by bells add to the participatory quality of the dance. ${ }^{5}$

Moreover, in communities in which the age set system still prevails, dancers are positioned in the spiral according to their age set identity. In many communities, elders occupy seats at the centre of the spiral. Dancers enter and leave the spiral by age set precedence, usually with the youngest age grades dancing continually. At the climax of the dance in 'Atolan, nearly the entire niyaro' and many of its guests move in the spiral, led by the call of an elder. These characteristics of the dance render malikoda an icon of the age set system. Indeed, 'Amis observers of malikoda tend to comment that a community has either a rigorous age set system or a weak one based upon the beauty and order of the dance, as opposed to the chaotic quality of the dance where the age set system is moribund.

A young man in the 'Atolan community underscored this understanding of malikoda in 2012 when he told me that "every year during the kiloma'an we fool ourselves into thinking that we follow the ways of our ancestors." One could hold this pretence because so much of the kiloma'an is dedicated to the dance, which realises a social order organised around the age set hierarchy. Malikoda positions dancers according to relevant social distinctions of gender, age and insider/outsider status. The dance realises the beauty of social relationships properly ordered and, through kinesthetic pleasure, induces positive cathexis with the values of the age set system (Figure 2 ). It is in this sense that the pretence is a powerful fantasy through which, as Victor Turner $(1967,43)$ might remark, the "individual is converted, for a while, into a loyal citizen" (see also Miller 2008; Seligman et al. 2008). Moreover, since one may, in theory, malikoda anywhere a community might gather, it is a relatively stable and mobile means to perform this pretence of mediated social differences, hierarchical order and a culturally specific value of beauty.

Given the role of malikoda as an indexical (in Rappaport's [1999] terms; see also Robbins 2001) realisation of social order, the dance would seem to obviate questions of sincerity (Seligman et al. 2008). As they move while holding hands, dancers assent to this social order quite apart from their motives or gloss on the event. In this sense, malikoda shares with participatory musical practices a fund of indexical meanings that seem to transcend linguacultural boundaries (Keil 1987; Turino 2008). Participation in malikoda generates allies who may not in other frameworks assent to the canonical meanings of the ritual: "The performing person may, paradoxically, be both an intentional agent and a sort of disclaimed or unintentioned agent who has no responsibility for the ritual message" (Basso 2001, 600). For this reason, malikoda provokes competing evaluations of agency and stance.

Questions of how the dance might make good guests, assert sovereignty or express Indigenous values appear in arguments concerning warrant (who should or should not animate malikoda). Below, I examine two ways that 'Amis people engage in these arguments: heritage and hospitality discourses. While heritage fits within bureaucratic regimes of verification and management, hospitality both creates and relativises boundaries, attempting to transform the other through practices that set the terms of ethical relatedness. 

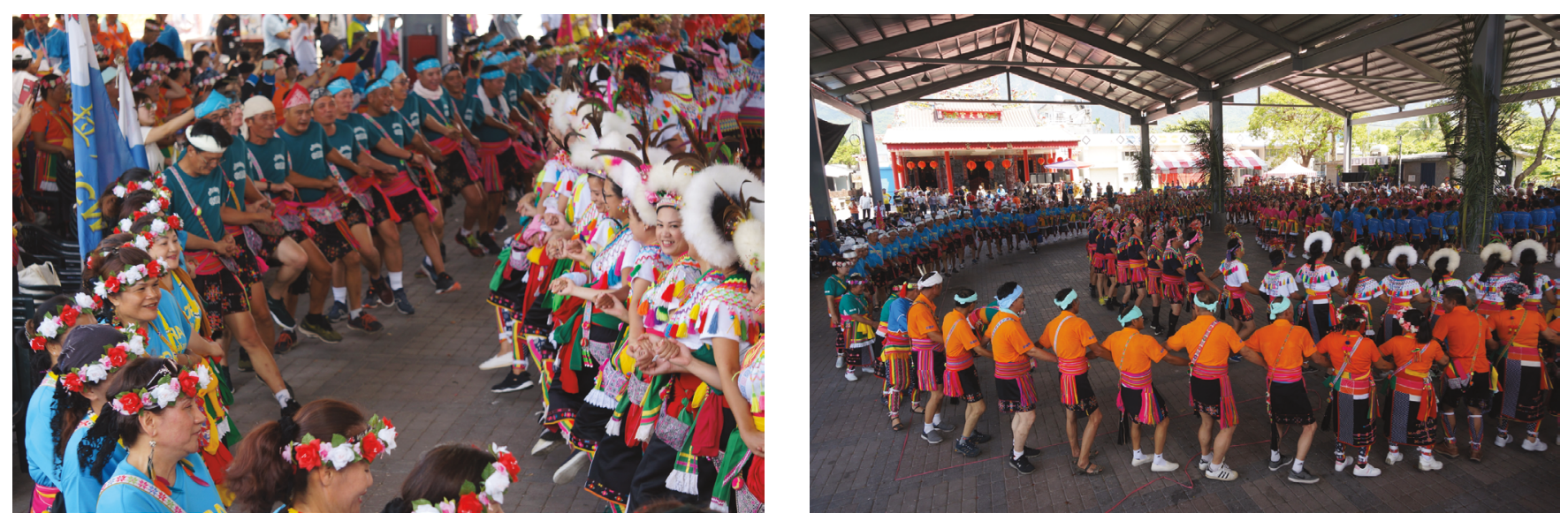

Figure 2: Dance as an icon of good relationships: Malikoda in the 'Atolan 'Amis Community, July 2019.

Source: Photographs by Hao-chuan Lien.

\section{Heritage - Is It Only about Ownership?}

In the terms outlined above, heritage regimes resolve the question of warrant through delegation; in other words, those who animate have been given permission (or even a bidding) by an authority capable of deciding who may realise heritage. This authority often resides in the state as a guarantor. Although Indigenous communities have interests in the maintenance of intangible heritage and its proper form, the state often steps in as an official arbiter between Indigenous and settler communities. State functions of regulating heritage thus generate effects of state sovereignty even in cases where heritage works on behalf of Indigenous communities.

To look more closely at how heritage discourses work, we take a detour to Montreal, where the Taiwanese Canadian Association's appropriation of malikoda for an October 2015 performance celebrating Double Ten, the national day of the ROC (Taiwan), sparked arguments in 'Amis communities and across social media platforms, most notably in a Facebook group titled "Is Respect So Hard? Stop Fouling (Whistle!)" (RESPECT n.d.). Detractors of the Montreal event pointed out mistakes in the handhold and the dancers' gracelessness (RESPECT 2015). Even a relatively well-executed performance by a government-sponsored troupe came under aesthetic scrutiny. The dance song was a Tafalong Pangcah piece, but the regalia was Fata'an Pangcah (TITV 2015b).

Attention to the minutiae of regalia and song form points out the problem of aesthetic fidelity, one of the felicity conditions for animation. Government ministries such as the Ministry of Foreign Affairs (MOFA), the Ministry of Culture and the CIP hoped that a standard template for performances would settle the issue.
However, aesthetic failure could also demonstrate an ethical lack. To the mostly Indigenous youth participating in "Respect," the wrong handhold or regalia were indices of more than misunderstanding: aesthetic shortcomings pointed out an unwillingness to consider the meaning of malikoda in specific 'Amis communities. Indigenous commentators on these performances employed the term respect to dispute malikoda's animation in non-Indigenous projects of national representation.

Official response to 'Amis protests underlined that malikoda was a symbolic resource not to be squandered. But what were the felicity conditions for animating this cultural heritage? Institutions charged with protecting Indigenous interests, such as the CIP, argued that it was sufficient to credit Indigenous communities as authors; civic organisations and national officials, as principals of cultural representation, could approve non-Indigenous dancers to animate this heritage. The problem was ensuring aesthetic credibility of dance gestures, tunes and regalia. Thus, representatives of the CIP and Professor Panay Mulu of the College of Indigenous Studies at Donghwa University both argued for a stricter set of guidelines for dancers to follow in international cultural performance tours (TITV 2015b, 1:12-1:36; see also TITV 2015a). They also advocated legal protections for Indigenous dances akin to copyright. In its role to promote Taiwanese soft power in the absence of formal international recognition, MOFA requested guidelines from CIP. These arguments would situate malikoda as the intangible cultural heritage of Taiwanese Indigenous people, not to be infringed by settler or other performers without a warrant. As a guarantor of cultural vitality, the state could step in and offer such a warrant for performances that respected 'Amis communities 
while employing their dance in contexts of national representation.

Settler appropriations of Indigenous dance appeared in a broader political context. Although it is now obvious that in settler colonial societies, performances of indigeneity, often by non-Indigenous people, are meant to accomplish the work of grounding settler polities in something other than institutions imported from the metropole (Deloria 1998), this problem is compounded in Taiwan by its precarious international position. The government of the ROC (Taiwan) had from 1945 until the late 1970s projected an image of itself as a base for the cultural, and ultimately political, recovery of its legitimate sovereignty over China. This program of Chinese Cultural Renaissance eroded with international recognition of the People's Republic of China (PRC) in the 1970s. Taiwanese political activists in the 1980s and 1990s also perceived it as an obstacle to democratisation. Rejection of narratives of national recovery opened ground for a multicultural, post-Chinese public culture that highlights Indigenous Taiwan. As a result, the need to disclose Indigenous heritage has become a means to display one's own democratic commitments. Not a matter of civic consciousness alone, it is one of the only means to imagine Taiwan outside of the current limitations of the PRC diplomatic embargo. ${ }^{6}$

This imperative to disclose Indigenous heritage compelled Taiwanese Canadians in Montreal to play Aboriginal. Would the standard template for malikoda, provided by CIP, plus the sincerity of ethnic Chinese performers guarantee that such necessary representations of indigeneity were felicitous? Note that again, these representations are a form of animation: to disclose Taiwanese culture, the performers in Montreal must put on regalia and malikoda to a recording. Their malikoda is also just one of an entire set of similar acts, including Hakka and Hoklo folk dances, ${ }^{7}$ that they must coordinate to animate the figure of "Taiwanese culture" on Double Ten.

Organisers of the Montreal event, thinking within this framework of Taiwanese heritage, found it difficult to understand the Indigenous people who posted criticism to the organisers' YouTube and Facebook pages. The charge that their parody of malikoda (which the organisers called "Mountain Folk Dance") was a misappropriation, argued one of these organisers, reflected only the resentments of the critics. To Indigenous people who pointed out that she failed to understand that the dance was a ritual, the organiser underlined her sincerity, even saying that her critics should buy a plane ticket and teach her to dance correctly. ${ }^{8}$

Throughout, the organiser aligned herself with what she called a "global outlook" (RESPECT 2015).
The conflict had much to do with scale, as well as the symbolic reduction (Tamen 2004) of 'Amis dance to one of several tokens of Taiwanese culture in global circulation. To the organisers, inclusion of malikoda demonstrated respect for Taiwanese Indigenous culture and represented Taiwaneseness in ways that would cause a Canadian audience to develop a favourable impression of Taiwan. Several commenters on "Respect" disagreed both about the scale at which the dance's perlocutionary effects should operate and the community for which these effects are intended. Familiar with the great diversity of malikoda styles, most 'Amis people would attest that each niyaro' has its own set of dances, which engage outside power (particularly that of the ancestors) on behalf of the niyaro'. A "global outlook," to those who commented on "Respect," must align with the global as envisioned from Indigenous communities (RESPECT 2015). Failing that, the organisers of the event could at least animate the dance adequately.

Heritage regimes attempt to situate culture as a resource whose animation can promote a social imagination of Taiwan as a multicultural, post-Chinese nation. In relationship to these state-centric discourses, Indigenous people employ heritage discourse to restrict warrants to animate malikoda. Recently, nearly all 'Amis communities have posted policies instructing guests concerning ritual protocol and warning that the niyaro' maintains ownership over all images and recordings that visitors might produce at their annual festivals. Shared on "Respect" and other forums, these policies animate an 'Amis/ Pangcah voice.

Although heritage discourse can serve as a means to assert ownership over cultural properties, it tends to reproduce structures in which Indigenous communities remain local cultures subordinated to settler colonial nationalism or tokens of a national culture in global circulation. However, heritage is not the only, or even primary, way that people in 'Amis communities describe and perform malikoda. Thus, to understand conflicts over who should malikoda, we need to turn to discourses that situate the dance as an act of hospitality, a dance that makes good hosts and good guests.

\section{Hospitality}

While most of the settler population think of malikoda as a dance in which everyone gets to participate, norms for participation are not that simple. Rather, the practice is relatively closed: First, because it should not be performed by those who do not have a warrant to perform it, nor in contexts in which it is not appropriate; and, second, because when visitors are invited to enter the dance, there is a protocol for including them that marks these visitors 
as outsiders. Ideally, by including the guests, malikoda absorbs them and mediates between these outsiders (as sources of power, fame or value) and the community. The stances that 'Amis people take on the dance range from one in which the dance is a sacred form that mediates between the community and ancestors to another stance in which visitors may be included as a feature of hospitality, as long as the visitors respect that the dance can never quite be their own. These stances differ across and within 'Amis communities, by ritual context and over the course of the several days of kiloma'an or ilisin. ${ }^{9}$

Among 'Amis communities, 'Atolan is relatively open to guests. At 'Atolan, one part of the last session of likoda during each day of kiloma'an brings guests into the spiral. The community also accepts new residents and friends as age set members after a period of probation, if the age set wishes to include these members. Disputes concerning inclusion focus on where guests can enter the dance spiral during the open dance. Since 2015, younger age sets have not allowed guests to enter their ranks. More senior age sets, for their part, resented the relegation of guests to the end of the spiral and largely ignored the ban.

Niyaro' along the Siugulan River and in the East Rift Valley tend toward relatively closed malikoda. In the Siugulan River Pangcah communities of Makota'ay and Cawi', only men malikoda during three nights of the festival, followed by women on the fourth night. For most of the ilisin, only members of the community can dance; on the third night, the community holds a banquet and invites guests, many from nearby Indigenous communities, to enter the dance for a 40 - to 60 -minute session. In Cawi', men not born in or married into the community can join an age set if accepted by the community as a member. Makota'ay, just across the Siugulan River from Cawi', only permits men born in the community to join. People in both communities explain the difference as a matter of emphasis. To many people in the Makota'ay community, ilisin is purely a ritual and hedged about with protocol, whereas people in Cawi' think of ilisin as both ritual and enjoyment. In Cawi', giving joy to the elders (and ancestors) watching the dance requires inclusion of guests that the elders love. As people in Cawi' have told me, ilsin communicates with the ancestors but also incorporates long-term residents and close friends into the "family of Cawi'."

Very few 'Amis communities exclude guests entirely. Even in relatively closed communities, one session of one day's events enjoins guests to enter the dance spiral. Guests are not entirely excluded, nor is participation fully open. Some amount of closure is necessary to make good guests. It is this closure, with its gesture to types of inclusion, that makes malikoda a type of sovereign assertion articulated through hospitality: by transforming the bodies of visitors into guests who assent, through dance, to the community's boundaries, ancestors and moral frameworks, including the community's relationship to land, malikoda asserts control over its boundaries and the bodies of those who enter therein. Questions of who can be a guest are thus part of a broader strategy of refusal (Simpson 2014) in which Pangcah communities reject the settler state's arrogation of membership reckoning. They are also a positive program of asserting the continued relevance of age set organisation.

\section{But who is a guest?}

If guests are sometimes allowed to enter the spiral, one might ask, "Who is a guest?" According to many 'Atolan 'Amis, lafang, guest, should not apply to the Mandarin term guanguang ke, tourist. The distinction between lafang and tourist is meaningful: lafang have some relationship to their hosts and, more importantly, are usually invited.

We see this usage more clearly in the practice of palafang across 'Amis communities or age sets, in which representatives of one group visit the other formally. Palafang stresses the extraordinary quality of the visit. Normally, members of an age set cannot visit the meeting place of an age set not adjacent to their own, but as lafang, they may enter without their visit constituting an ethical breach. While communities do not usually join each other's malikoda, and certainly never in their own regalia, here they are received. Those received as lafang in these contexts are aware that the event suspends norms for inter-age set or inter-niyaro' relationships. The example of palafang suggests that lafang are subjects constituted by a peculiar context. To understand this context, we could look further at forms of affect that emerge in inter-age set or intercommunal relationships.

Notions of propriety and avoidance that 'Amis call ngodo govern these relationships. Feeling mangodo, someone might slink away, looking down, to the outside of a circle upon the arrival of those in a higher age group, indications of formal meetings about to occur or a sense that one is out of place. An affectual response arising from social discomfort, ngodo reinforces community boundaries and age set hierarchies (Hsieh 2011; Liu 1965). Embodying ngodo distinguishes polite people from those whose eyes light up when a jaunt through the niyaro' reveals a table with ready drinks in a courtyard just ahead. Those who are mangodo know to resist, with a pained grimace, an invitation to sit down at a table with an age set removed from one's own or at another family organisation's gathering. Yet, one cannot always avoid being a lafang. Not accepting invitations leaves one at a 
deficit: "People who are mangodo (that is, too polite) are left hungry" (mangodoay ko macahiway). In response to a lafang's discretion, hosts might say, "o maan ko kangodoan" ("why so polite?") and address the lafang as widang (friend) or even tongsie (borrowed from Mandarin tongxue, classmate), non-hierarchical terms generally reserved for age mates.

Ngodo gives us a better understanding of how malikoda connects to the problem of guests and, from there, to hospitality. Good guests embody kangodoan. They remain deeply aware that although they are included, the dance is still a closed one, in which they are still relative outsiders.

Do good dances make good guests? Possibly. However, good guests are not the only guests at events like kiloma'an today. In recent years, those charged with managing kiloma'an employed heritage discourses in their procedures and public notices, hoping that gestures to intellectual property and intangible heritage law could restrain photographers, restrict speechifying politicians and relegate guests to manageable locations. Whether and how these guests should enter malikoda remains a difficult question.

Like many disagreements in 'Atolan today, this controversy often falls along age lines. A look at malikoda between 2015 and 2019 in 'Atolan shows these fault lines well. After the announcement that visitors could enter the dance spiral, none of the four youth age sets broke their ranks to admit guests. Lakayakay arranged for visitors who wanted to dance to join at the end of the spiral, after the ranks of the youngest age group. Some youth joined these guests to teach them steps and preserve order. Although this compromise placated the community's youth, most of the middle-aged and all of the elderly age sets admitted visitors into their own ranks. Several members of older age sets complained to me about what they saw as increasing pressure to close the dance. "If we don't ask them to join, we won't show them hospitality. Will 'Atolan's festival remain so beautiful and famous?" they asked.

Nonetheless, it is possible to see hospitality in a different light. Reflecting on an analogy between kiloma'an and the Lunar New Year festival, 'Amis popular musician Suming Rupi, who is from 'Atolan, asked at one of his 2015 Taipei concerts whether people gave enough thought to tourist practices. "What if," he said,

I were to enter your house uninvited on New Year's Eve with my camera and ask to join your family around the hearth? Wouldn't you feel it was awkward? Well, it might feel like that to me if you come as a tourist to kiloma'an: After all, the dance is our New Year's Eve family meal. ${ }^{10}$
Suming suggests a kind of caution. After all, it is rare but not impossible for guests to come to another family's New Year's celebration. Suming's Taipei audience would know that being such a guest would be awkward. Among the settler population, family events like New Year's celebrations or weddings are peculiar, with each family having its own set of traditions (Adrian 2003); one would expect the celebration not to be quite the same as one's own family's and be very careful not to overstep one's limits. Dutiful hosts would try to make you feel at home, would even say, "Think of our house as yours;" but you would never make the mistake of feeling that way. The hypothetical situation Suming describes is, for a settler Taiwanese person, a situational translation of ngodo. Rather than warning Taipei people away, Suming provoked them to think about the kind of affect they should cultivate were they to visit his niyaro' during its most important annual ritual.

Suming's concert talk addressed the problem of alignment, attempting to create a framework that could align the images settler guests maintain of the 'Amis harvest festival with understandings of kiloma'an current among 'Amis youth. But I also wonder whether this analogy too greatly restricts the politics of ritual as a kind of family affair. Although kiloma'an does, in fact, derive from the root loma', meaning house (in both the architectural and kinship senses), kiloma'an actively courts guests so that the community may stand in the position of ciloma'ay, house master or host, in relationship to lafang, guests. Being a lafang places one in relationships of obligation and respect with ciloma'ay, who provide the place and resources for a meeting. For our thinking about sovereign assertion, it is also useful to recall that ciloma'ay own the house and maintain the land. Perhaps, however, Suming's fans have managed to align interpretations with the statements of their 'Amis idol. Many of Suming's fans do visit kiloma'an as the age set name influenced group, Latiefen (La-Diehard Fans), and dutifully join hands only at the end of the spiral. As good guests, they assent to the outcome of an event that asserts the niyaro' as an enduring political organisation and not just a cultural attraction.

'Atolan 'Amis and settler visitors may have more difficulty aligning their experiences of kiloma'an without the framing the age set system provides. After all, as several elders in 'Atolan have told me, one can think of the kiloma'an as a kind of ritualised military exercise as well as a celebration of the harvest. In this context, the malikoda is not merely a celebratory dance meant for enjoyment but one of the ways the niyaro' asserts its perduring sovereignty, muted but still discernible in a ritual framework. Malikoda iconises social order and indexes 
a territorial and social claim: This is our land and our ocean. We are ciloma'ay (hosts) and you lafang (guests). To be invited to malikoda is thus to be incorporated in the local social and cosmological order, persuaded to submit to local sovereignty. Through the order that it imposes kinesthetically, the dance compels visitors to recognise constraints on their actions. If the dance succeeds, guests may begin to feel these constraints as kangodoan.

\section{Conclusion: The Limits of Ritual}

Nonetheless, colonial administrators often see malikoda as a performance for their benefit; and the settler colonial mainstream continues to represent the dance as a practice of "carefree Mountain People," easily contained within their own Taiwanese heritage. In other words, the ways that settler colonial institutions have tended to interpret malikoda reduce the dance to a symbolic representation of one of Taiwan's many cultural groups. These institutions may befriend "Indigenous culture" but frame it in ways that diminish indexical meanings created by participation in the dance. This problem perhaps marks the limits of hospitality, if not of ritual (to riff on Adam Seligman's [et al. 2008] notion of the "limits of sincerity").

In other words, the way that a good host might assert sovereignty is limited both by the felicity conditions of hosting as a particular kind of perlocutionary act and also by the possibility that there might not always be a shared framework for defining what responses guests should make now that the ritual has obligated them to the host. Whatever shared frameworks do operate may also act as a kind of mutual encompassment, in which the dance produces the niyaro' as a host whose vibrant "culture" can nonetheless stand as an image of Taiwanese cultural vitality, allowing the state to file the age set system into a "safety zone" of unthreatening Indigenous difference (Lomawaima and McCarty 2006; see also Goodyear-Ka'opua 2013). ${ }^{11}$

If closed dances are like good fences, malikoda might still provide some method to align disparate understandings of Indigenous-settler relationships. The dance may yet make claims on visitors. To maintain these claims after the dance has ended requires that the figure animated in dance remains a durable structure of complicity that can afford commitment to a shared practice in the context of contention and difference (Hatfield 2010). If animation can produce such structures, issues surrounding ritual assertions of sovereignty, like malikoda, have less to do with interpretation per se than they do about the distribution of interpretive work, when and how shared interpretations of an assertion are necessary to maintain commitment to the outcome of ritual. Nonetheless, these outcomes may remain ambivalent, serving as evidence for both the continuity of 'Amis communities as polities and the cultural vitality (and distance from China) of a Taiwanese multicultural nation.

Thus, questions of closure and enrolment have bearing on strategies of sovereign assertion, not only in the obvious sense often described as cultural appropriation but, more broadly, in terms of framing and alignment. Good dances produce a shared framework in which all participants may assent, at least during the event, to the claims of would-be sovereign entities. How this social effect of assent might operate outside of, or after, the event requires alignment across social contexts and discourses. This alignment remains in tension with the outcomes of participatory musical practice but is not necessarily opposed to it, as reference to a ritual frame (Seligman et al. 2008) might suggest. Rather, sincerity, in the sense of commitment to a shared frame of meaning or value, is the product of animation as an intermediate form of social practice, of alignment, as well as enrolment or interpretation.

In that regard, heritage regimes, which reduce malikoda to a cultural property that may be animated only within a strict set of guidelines, may offer a framework akin to sincerity, defined here as a commitment to a prescribed interpretation of the dance. The ability of heritage regimes to bring some interpretive order to participatory events explains their appeal to at least some Indigenous cultural activists. The role of heritage regimes in regulating stance suggests why heritage and hospitality discourses appear entangled.

But I would like to return to the powerful effects of hospitality as a perlocutionary act, even as I keep in mind the ways that it remains troubled. The linking principle, as Asch (2014) describes it, serves to establish social relatedness in a noncoercive yet ordered fashion, in which those linked do not require a single interpretive framework or fixed boundaries of insiders and outsiders to live together in good faith. Malikoda is an icon of such linking practices. As long as we dance, we are always grasping the hand of the Other. Our stances on who may animate the dance remain in tension with our stances on how we and others act as good hosts or guests. Exploring how something resembling sovereignty might be animated in dance might then point us beyond sovereignty, to other ways of living together. I felt these possibilities most strongly in the following episode from 'Atolan, with which I conclude this essay:

After rejecting my request to record him singing 'Atolan's 14 likoda because "culture cannot be dispersed outward, and you haven't worked out my copyright,” 
the late 'Atolan 'Amis singer and leader of the 'Atolan 'Amis community Halu (Pan Ching-Tien) took my hand, sang the call and demanded my response. My age mates joined us, a boy poured drinks, and the spiral unfolded like ocean waves or the undulations of fern shoots in the mountains. I was forced to remember that Halu was ciloma'ay and I lafang. His parody of copyright was more eloquent than any amount of legal procedure spun out by CIP at the request of MOFA.

DJ W. Hatfield, Assistant Professor, Liberal Arts Department, Berklee College of Music, Boston, Massachusetts, United States.Email: dhatfield@ berklee.edu.

\section{Acknowledgements}

This article is dedicated to the memory of Kakita'an ciHalu (Pan Ching-Tien), 'Atolan 'Amis musician, elder and leader. I would like to thank the 'Atolan 'Amis and Makota'ay Pangcah communities for their hospitality and patience with this awkward dancer, particularly to Ama ciAki, Suming Rupi, Ina ciAmoy, Alang Ro'en, Siki Sufin, Rahic Talif, Faki ciPanay (Shen Tai-mu), Shen Hsiu-li, Kao Shen-hai, my age mates in Lakancin and little brothers in Lakayakay and Laciensi, the Lai'ic age set of Cawi', Nikar (Chen Shan-shan), Canglah (Lin Ming-chih), Hana Kliw, Caya Potal, Ro'en Alang, Hsu Sheng-ming, Anu Kaliting Sadipongan and Iyo Kacaw; thanks also to Ado Kaliting Pacidal and Niwa Maibut for asking the right questions. Ira kamo nga' ira kako. Thanks are also due to Yang Chien-chang, Wang Ying-fen, Teri Silvio, Robert Weller, Lucia Liu, Matt West, Lin Wei-ping, Kerim Friedman, Tomo Sugimoto, Futuru Tsai, Daryl Sterk and Chen Qing-yuan for conference invitations and careful readings of previous versions of this essay. I would also like to thank the anonymous reviewers for Anthropologica who pushed me to think more closely about issues of sovereignty and animation. Funding for this work was provided by the Fulbright Foundation, the Asian Cultural Council and the Berklee College of Music Office of Faculty Development. Finally, many thanks to Stanley Chang for enduring long absences.

\section{Notes}

1 Kiloma'an, also known as ilisin, is a ritual associated with the celebration of the harvest among 'Amis/Pangcah peoples on Taiwan's east coast. Although known officially as Amis, several 'Amis groups prefer the ethnonym Pangcah. Throughout this article I employ 'Amis or Pangcah in ways that defer to the preferences of the particular community or person under discussion; for example, I refer to the 'Atolan 'Amis community but the Makota'ay Pangcah community. All 'Amis/Pangcah groups recognise each other as belonging to the same group while maintaining that the name they prefer is the "right" ethnonym. Another ethnonym that appears in this paper is Paylang, a Taiwanese Indigenous term that refers to the majority settler, ethnic Chinese population.

2 "Upstream/downstream," "upstairs/downstairs" and "branches/shoots" are metaphors commonly used in "Atolan to refer to relationships among age sets. The age set system, in which nearly all men are initiated upon adulthood, is the core social organisation of most 'Amis communities, serving a wide variety of decision-making, administrative and defensive functions (see Lin 2018; Tsai 2103).

3 See, for example, Comaroff and Comaroff (2016), Hansen and Stepputat (2006), Jennings (2011), and Rutherford (2012). My refusal to mention the writer who inspired much of this theorising is intentional.

4 Erich Steinman (2016), as well as Jeff Corntassel (2012b), pays particular interest to land-based, sustainable actions rooted in what Glen Coulthard (2010) has called "grounded normativities." Working in the Australian context, Daniel Fisher (2013) shows how the Larrakia created state-like institutions to manage guests camping in Larrakia territory; unlike the state, however, these institutions were grounded in care rather than a nexus of occupation and deadly force.

5 These qualities resemble Turino's (2008) definition of participatory musical performances.

6 I need not remind the reader that the PRC has never governed Taiwan.

7 Hoklo and Hakka are names of two of Taiwan's settler ethnic groups.

8 I refer to the development of these conversations as they unfolded in the niyaro' and especially on the Facebook group "Respect" and the Montreal organiser's YouTube channel. Currently, both threads of conversation have been removed from the internet.

9 Kiloma'an and ilisin are two widely circulating names for the annual ritual. Generally speaking, ilisin circulates among groups employing the ethnonym Pangcah. In many contexts, malikoda is synonymous with the ritual.

10 Suming Rupi's remarks at a 2015 concert in Taipei. There is no widely available recording or published form of these remarks.

11 I thank one of the anonymous reviewers of this article for pointing out that the encompassment here is both total and mutual.

\section{References}

Adrian, Bonnie. 2003. Framing the Bride: Globalizing Beauty and Romance in Taiwan's Bridal Industry. Berkeley: University of California Press.

Alfred, Taiaiake. [1999] 2009. Peace, Power, Righteousness: An Indigenous Manifesto, 2nd edition. Oxford: Oxford University Press.

— 2005. "Sovereignty." In Sovereignty Matters: Locations of Contestation and Possibility in Indigenous Struggles for Self-Determination, edited by, Joanne Barker, 33-50. Lincoln: University of Nebraska Press.

Asch, Michael. 2014. On Being Here to Stay: Treaties and Aboriginal Rights in Canada. Toronto: University of Toronto Press. 
Asch, Michael, John Borrows, and James Tully, eds. 2018. Resurgence and Reconciliation: Indigenous-Settler Relations and Earth Teachings. Toronto: University of Toronto Press.

Austin, J.L. 1962. How to Do Things with Words. Oxford: Clarendon Press.

Barker, Joanne. 2005. "For Whom Sovereignty Matters." In Sovereignty Matters: Locations of Contestation and Possibility in Indigenous Struggles for Self-Determination, edited by Joanne Barker, 1-31. Lincoln: University of Nebraska Press.

Basso, Ellen. 2001. "Response to Joel Robbins, 'Ritual Communication." Current Anthropology 42 (5): 600-601. https://doi.org/10.1086/322557.

Biolsi, Thomas. 2006. "Imagined Geographies: Sovereignty, Indigenous Space, and American Indian Struggle.” American Ethnologist 32 (2): 239-259. https://doi. org/10.1525/ae.2005.32.2.239.

Blackburn, Carole. 2009. "Differentiating Indigenous Citizenship: Seeking Multiplicity in Rights, Identity, and Sovereignty." Cultural Anthropology 25 (2): 235-262. https://doi.org/10.1111/j.1548-1425.2008.01103.x.

Cattelino, Jessica R. 2008. High Stakes: Seminole Gaming and Sovereignty. Durham, NC: Duke University Press.

— . 2010. "The Double Bind of American Indian Need-Based Sovereignty." Cultural Anthropology 25 (2): 235-262. https://doi.org/10.1111/j.1548-1360.2010.01058.x.

Chao, Chih-fang. 2009. "Holding Hands to Dance: Movement as Cultural Metaphor in the Dances of Indigenous Peoples in Taiwan." Journal for the Anthropological Study of Human Movement 16 (1-2): 1-9. https://jashm.press. uillinois.edu/16.1_2/chao.html.

Cocks, Joan. 2014. Sovereignty and Other Delusions. New York: Bloomsbury Academic.

Comaroff, Jean, and John L. Comaroff. 2016. The Truth about Crime: Sovereignty, Knowledge, Social Order. Chicago: University of Chicago Press.

Corntassel, Jeff. 2012a. "Living in a Longer Now: Moving beyond the State-Centric System." In For Indigenous Minds Only: A Decolonization Handbook, edited by Waziyatawin and Michael Yellow Bird, 85-98. Santa Fe: School of American Research Press.

_ 2012b. "Re-envisioning Resurgence: Indigenous Pathways to Decolonization and Sustainable SelfDetermination." Decolonization: Indigeneity, Education, and Society 1 (1): 86-101. https://jps.library.utoronto.ca/ index.php/des/article/view/18627.

Coulthard, Glen. 2010. "Place against Empire: Understanding Indigenous Anti-Colonialism." Affinities: A Journal of Radical Theory, Culture, and Action 4 (2): 79-83. https://ojs.library.queensu.ca/index.php/affinities/article/ view/6141.

—. 2014. Red Skin, White Masks: Rejecting the Colonial Politics of Recognition. Minneapolis: University of Minnesota Press.

Council of Indigenous Peoples (CIP). 2018. "1/107 Taimin Xianshi Yuanzhuminzu Renkou" [Indigenous Population in Cities and Counties of Taiwan and Fujian]. Yuanzhumin Renkou Tongji Ziliao [Statistical Information on Indigenous Population]. Accessed 6 March 2020. https://www.apc.gov.tw/
portal/docDetail.html?CID $=940 \mathrm{~F} 9579765 \mathrm{AC} 6 \mathrm{~A} 0 \&$ $\mathrm{DID}=0 \mathrm{C} 3331 \mathrm{~F} 0 \mathrm{EBD} 318 \mathrm{C} 2465 \mathrm{BB} 6994589 \mathrm{C} 30 \mathrm{E}$.

Deloria, Phillip J. 1998. Playing Indian. New Haven, CT: Yale University Press.

Fisher, Daniel. 2013. "Becoming the State in Northern Australia: Urbanisation, Intra-Indigenous Relatedness, and the State Effect." Oceania 83 (3): 238-258. https://doi. org/10.1002/ocea.5023.

Goffman, Erving. 1974. Frame Analysis: An Essay on the Organization of Experience. New York: Harper and Row.

Goodyear-Ka'opua, Noelani. 2013. The Seeds We Planted: Portraits of a Native Hawaiian Charter School. Minneapolis: University of Minnesota Press.

Hansen, Thomas Blom, and Finn Stepputat. 2006. "Sovereignty Revisited." Annual Reviews in Anthropology 35: 295-315. https://doi.org/10.1146/annurev.anthro.35.081705.123317.

Hatfield, DJ W. 2010. Taiwanese Pilgrimage to China: Ritual, Complicity, Community. New York: Palgrave Macmillan.

Hodgson, Dorothy L. 2002. "Precarious Alliances: The Cultural Politics and Structural Predicaments of the Indigenous Rights Movement in Tanzania." American Anthropologist 104 (4): 1086-1097. https://doi.org/10.1525/ aa.2002.104.4.1086.

Hsieh Fu-kang. 2011. Wan Zuowei Yizhong Zuqun Rentong [Play as a Type of Ethnic Identity]. MA thesis, Department of Anthropology, National Taiwan University.

Jennings, Ronald C. 2011. "Sovereignty and Political Modernity: A Genealogy of Agamben's Critique of Sovereignty." Anthropological Theory 11 (1): 23-61. https://doi.org/10.1177/1463499610395443.

Kao Te-yi. 2016. "Buluo Farenhua zhi Ruogan Keti yu Tiaozhan: Yi ‘Buluo Gongfaren Zuzhi Shezhi Banfa Caoan’ wei Lie de Tantao" [Several Questions and Challenges of Incorporation of Indigenous Communities: Reflections on the Draft Law to Establish Indigenous Public Corporations]. Taiwan Yuanzhumin Yanjiu Luncong [Taiwan Indigenous Studies Review] 20: 19-56. https://doi.org/10.29763/TISR.

Keil, Charles. 1987. "Participatory Discrepancies and the Power of Music.” Cultural Anthropology 2 (3): 275-283. https://doi.org/10.1525/can.1987.2.3.02a00010.

Kockelman, Paul. 2004. "Stance and Subjectivity." Journal of Linguistic Anthropology 14 (2): 127-150. https://doi. org/10.1525/jlin.2004.14.2.127.

Lomawaima, K. Tsianina, and T.L. McCarty. 2006. "To Remain an Indian”: Lessons in Democracy from a Century of Native American Education. New York: Teachers College Press.

Lin Fang-cheng. 2018. "Wenhua Yichan de Shufu huo Huwei? Yi Amis Yinyuejie de Wenhua Shijian yu Chuangzuo Nengdongxing wei Lie" [Protection or Bondage of Cultural Heritage? Cultural Practice and Creative Agency in the 'Amis Music Festival]. Minsu Quyi [Journal of Chinese Ritual, Theatre, and Folklore] 200: 137-200. https://doi.org/10.30157/JCRTF.

Liu Bin-xiong. 1965. Xiuguluan Ameizu de Shehui Zuzhi [The Social Organization of Siuguluan 'Amis]. Taipei: Academia Sinica.

Manning, Paul. 2010. "The Semiotics of Brand.” Annual Review of Anthropology 39: 33-49. https://doi.org/10.1146/ annurev.anthro.012809.104939. 
Manning, Paul, and Ilana Gershon. 2013. "Animating Interaction.” Hau: Journal of Ethnographic Theory 3 (3): 107-37. https://doi.org/10.14318/hau3.3.006.

Martineau, Jarrett. 2015. "Rhythms of Change: Mobilizing Decolonial Consciousness, Indigenous Resurgence, and the Idle No More Movement." In More Will Sing Their Way to Freedom: Indigenous Resistance and Resurgence, edited by Elaine Coburn, 229-253. Halifax: Fernwood.

Miller, Kiri. 2008. Traveling Home: Sacred Harp Singing and American Pluralism. Urbana-Champaign: University of Illinois Press.

Nadasdy, Paul. 2012. "Boundaries among Kin: Sovereignty, the Modern Treaty Process, and the Rise of Ethno-Territorial Nationalism among Yukon First Nations." Comparative Studies in Society and History 54 (3): 499-532. https://doi. org/10.1017/S0010417512000217.

- 2017. Sovereignty's Entailments: First Nation State Formation in the Yukon. Toronto: University of Toronto Press.

Nozawa, Shunsuke. 2013. "Characterization." Semiotic Review 3. https://www.semioticreview.com/ojs/index.php/sr/ article/view/16 (accessed 6 March 2020).

Panay Mulu. 2008. "Ameizu Fongnianji Gewuzhong Fanfu Xingshi zhi Yanjiu" [Repetitive Forms in 'Amis Harvest Festival Dance Musics]. Taiwan Yuanzhuminzu Yanjiu Jikan [Taiwan Journal of Indigenous Studies] 1 (3): 129 147. https://doi.org/10.29910/TJIS.200809.0005.

_ 2010. "Shishou Fongbin Ameizu Fongnianjige de Fenxi Yanjiu" [An Analysis of Ten Fongbin 'Amis Harvest Festival Songs]. Taiwan Yuanzhuminzu Yanjiu Jikan [Taiwan Journal of Indigenous Studies] 3 (3): 197-224. https://doi.org/10.29910/TJIS.201009.0007.

Pictou, Sherry M. 2015. "Small 't' Treaty Relationships without Borders: Bear River First Nation, Clam Harvesters, the Bay of Fundy Marine Centre and the World Forum of Fisher Peoples." Anthropologica 57 (2): 457-467. https://www.jstor.org/stable/26350454.

Povinelli, Elizabeth A. 2002. The Cunning of Recognition: Indigenous Alterities and the Making of Australian Multiculturalism. Durham, NC: Duke University Press.

Rappaport, Roy A. 1999. Ritual and Religion in the Making of Humanity . Cambridge: Cambridge University Press.

RESPECT. n.d. "Zunzhong Youmeiyou Nama nan? Jinzhi Fangui (Chui Xiao)" [Is Respect That Hard? Stop Fouling (Whistle!)]. Accessed 6 March 2020. https://www.facebook. com/dontdothatinournation/.

_ 2015. "Zunzhong Youmeiyou Nama nan? Jinzhi Fangui (Chui Xiao)" [Is Respect That Hard? Stop Fouling (Whistle!)] public comments. 11 October-10 November, (removed late 2015/early 2016).

Rifkin, Mark. 2017. Beyond Settler Time: Temporal Sovereignty and Indigenous Self-Determination. Durham, NC: Duke University Press.

Robbins, Joel. 2001. "Ritual Communication and Linguistic Ideology: A Reading and Partial Reformulation of Rappaport's Theory of Ritual." Current Anthropology 42 (5): 591-614. https://doi.org/10.1086/322557.

Rutherford, Danilyn. 2012. Laughing at Leviathan: Sovereignty and Audience in West Papua. Chicago: University of Chicago Press.
Seligman, Adam B., with Robert P. Weller, Michael J. Puett, and Bennet Simon. 2008. Ritual and Its Consequences: An Essay on the Limits of Sincerity. Oxford: Oxford University Press.

Semaylay i Kakubaw (Lai Chun-chao). 2017. "Buluo Faren shi Shenma ne Daodi? Cong Faren, Gong Faren de Gainian Tanqi" [What Is a Tribal Corporation, Anyway? A Discussion of Public Legal Persons]. Quanguo Lüshi [Taiwan Bar Journal] 21 (11): 80-98.

Shih Cheng-fong. 2012. "Yuanzhuminzu Zhuquan yu Guojia Zhuquan" [Indigenous Sovereignty and National Sovereignty]. Taiwan Yuanzhumin Yanjiu Luncong [Taiwan Indigenous Studies Journal] 12: 1-56. https:// doi.org/10.29763/TISR.201212.0001.

Silvio, Teri. 2010. "Animation: The New Performance?" Journal of Linguistic Anthropology 20 (2): 422-438. https://doi.org/10.1111/j.1548-1395.2010.01078.x.

- 2019. Puppets, Gods, and Brands: Theorizing the Age of Animation from Taiwan. Honolulu: University of Hawai'i Press.

Simpson, Audra. 2014. Mohawk Interruptus: Political Life across the Borders of Settler States. Durham, NC: Duke University Press.

Simpson, Leanne Betasamosake. 2013. "I Am Not a Nation State.” Unsettling America, November 6. https:// unsettlingamerica.wordpress.com/2013/11/06/i-am-not-anation-state/ (accessed 8 August 2020).

Steinman, Erich W. 2016. "Decolonization Not Inclusion: Indigenous Resistance to American Settler Colonialism." Sociology of Race and Ethnicity 2 (2): 219-236. https://doi. org/10.1177/2332649215615889.

Sturm, Circe. 2017. "Reflections on the Anthropology of Sovereignty and Settler Colonialism: Lessons from Native North America." Cultural Anthropology 32 (3): 340-348. https://doi.org/10.14506/ca32.3.03.

Taiwanese Indigenous Television (TITV). 2015a "Cuowu Wudao Zhanshang Guoji Que Wenhua Suzhi Zaopi” [Missteps Taken to an International Audience: Performances that Lack Cultural Value Come under Criticism]. TITV News, 11 March. https://youtu.be/eicn_S-jHgY (accessed 28 February 2020).

_ 2015b "Mongtelo Tongxianghui Qing Shuangshi Wudao Cuowu Baichu" [Montreal's Taiwanese Association Fouls up Dancing at National Day Celebration]. TITV News, 15 October 2015. https://youtu.be/h8NOoaLg5_k (accessed 28 February 2020).

Tamen, Miguel. 2004. Friends of Interpretable Objects. Cambridge, MA: Harvard University Press.

Tsai Cheng-liang Futuru. 2013. "Cong Rentong dao Shijian de Kunjing: Dangdai Dulan Ameizu Nianling Zuzhi Zhong de Shehui Zhixu yu Gonggong Shiwu Yunzuo" [The Struggles from Identity to Practice: Contemporary Social Order and Public Affairs in the Age Organization among 'Atolan 'Amis]. Taiwan Yuanzhuminzu Yanjiu Jikan [Journal of Taiwan Indigenous Studies] 6 (3): 77-117. https://doi. org/10.29910/TJIS.

Tsai Ying-wen. 2016. "Full Text of President Tsai Ying-wen's Apology to Indigenous People" Focus Taiwan News, 1 August. https://focustaiwan.tw/politics/201608010026 (accessed 6 March 2020).

Turino, Thomas. 2008. Music as Social Life: The Politics of Participation. Chicago: University of Chicago Press. 
Turner, Dale Anthony. 2006. This Is Not a Peace Pipe: Towards a Critical Indigenous Philosophy. Toronto: University of Toronto Press.

Turner, Victor. 1967. The Forest of Symbols: Aspects of Ndembu Ritual. Ithaca, NY: Cornell University Press.

Wang Ying-fen. 2008. Tingjian Zhimindi: Heize Longchao yu Zhanshi Taiwan Yinyue Diaocha (1943) [Listening to the Colony: Kurosawa Takamoto and the Wartime Survey of Formosan Music (1943)]. Taipei: National Taiwan University Press.

Willow, Anna J. 2013. "Doing Sovereignty in Native North America: Anishinaabe Counter-Mapping and the Struggle for Land-Based Self-Determination.” Human Ecology 41 (6): 871-884. https://doi.org/10.1007/s10745-013-9593-9. 